\title{
Higher Education and Student Employment Needs*
}

\author{
HORACE D. BEACH**
}

\begin{abstract}
Harold Macmillan, former Prime Minister of the United Kingdom, recounted what an Oxford professor said back in the thirties about higher education. The professor introduced his course with these words: (14)

Gentlemen - you are now about to embark upon a course of studies which will occupy you for two years. Together they form a noble adventure. But I would like to remind you of an important point. Some of you, when you go down from the University will go into the Church, or to the Bar, or to the House of Commons, to the Home Civil Service, to the Indian or Colonial Services, or into various professions. Some may go into the Army, some into industry and commerce; some may become country gentlemen. A few - I hope very few - will become teachers or dons. Let me make this clear to you. Except for the last category, nothing that you will learn in the course of your studies will be of the slightest possible use to you in after life - save only this - that if you work hard and intelligently, you should be able to detect when a man is talking rot, and that, in my view, is the main, if not the sole purpose, of education.
\end{abstract}

This is one view of higher education, and an important view. However, there is a hereafter for college and university students, in which they must survive and carry on. In this paper I shall focus on the employment aspect of the hereafter. What is the impact of a college or university education on students' future employment?

\section{RESUME}

L'Enseignement supérieur et les besoins en matière d'emplois pour les étudiants

Harold Macmillan, ancien premier ministre du Royaume Uni, raconta ce que dit un professeur d'Oxford au cours des années 30 au sujet de l'enseignement supérieur. Le professeur présenta son cours avec les propos suivants:

Messieurs - vous êtes sur le point d'entamer un programme d'études qui vous absorbera pour deux années. L'ensemble constitue une noble aventure. Quelques uns d'entre vous, en

*Presented at the Conference on "The Impact of College on Students - The Canadian Experience" at Memorial University of Newfoundland, Regional College at Corner Brook, 1 June, 1977.

**Director, Counselling Centre, University of Victoria. 
quittant l'université, entreront dans l'église, ou au barreau, ou aux Communes, ou dans la fonction publique intérieure, ou dans les missions aux Indes ou dans les colonies, ou encore dans l'une des diverses professions libérales. D'autres pourront faire carrière dans l'armée, dans l'industrie ou dans le commerce et d'autres encore deviendront gentilshommes propriétaires. Quelques-uns seulement, j'espère que le nombre sera très restreint, deviendront professeur ou tuteur universitaire. Je tiens à bien préciser ce qui suit. Exception faite de la dernière catégorie, rien de ce que vous apprendrez ne vous sera d'une utilité quelconque. Rien à l'exception d'un principe: si vous avez travaillé dur et intelligemment, vous devriez pouvoir déceler quand un homme ne dit que des bêtises, et cela, à mon avis, est le principal objectif, le seul objectif d'une formation académique.

Il s'agit là d'une seule approche à l'enseignement supérieur, bien qu'une approche importante. Toutefois, il existe une vie au delà de leurs années d'étude au collège ou à l'université pour les étudiants dans laquelle il leur faut survivre et se débrouiller. Dans cette étude, je mettrai au point la question de l'emploi après les années collégiales ou universitaires. Quel est l'impact d'une formation collégiale ou universitaire sur l'emploi futur de l'étudiant?

For two decades and roughly since Sputnik, a university degree was virtually a ticket into a good job, a job with more status and pay than the high school student could hope for. University was a good investment, it was the thing to do; teachers and parents, business and government, all encouraged youth to get more education, to go to college and university and better themselves.

Now all that has changed. Instead of sitting back to choose among three or four job offers, students are putting in a score of applications and scrambling for the limited jobs available. Students are unemployed, on U.I.C. and even on welfare. The news media feature personal tragedies of students without a future. Professional writers (3) purport to show that a university education is no longer a good investment. Manpower centres add fuel to the fire with local data. The Vancouver office reported early this year that nearly 3,500 highly-educated young people were looking for jobs, including 91 with Ph.D.'s and 350 with Master's degrees, from various disciplines such as physics, chemistry, and psychology, and that only 178 were placed in jobs in the last three months of 1976. The Victoria Manpower office announced that 279 professionals were without jobs, including 130 teachers, 42 university instructors, 45 nurses, and 62 social workers. It was suggested that the university was adding to unemployment by continuing to churn out graduates, and that it should consider restricting enrollment. Finally, the Minister of Manpower and Immigration referred to the "disturbing trend in post-secondary institutions to overlook the job needs of our economy", and went on to say, "It is time for us in Canada to reorient our educational systems so that young people get the education and training that will assure them of employment" (8). There is an ominous message in such public statements and news stories:it is that the universities are not preparing students for the world of work, and that the universities are somehow helping to create unemployment. What are the facts? How did all this happen?

A casual and uneducated answer might be that it all started south of the border. However, the Canadian problem was hardly caused by a similar problem in the United States, although we might have observed theirs and anticipated our own. For twenty-five years there was a boom in higher education (12) in the United States, peaking in 1969 when 
$44 \%$ of the age group went to university. From then on, however, the situation turned around. A total of $9.3 \%$ of the 1972 graduates were unemployed in October of that year, with higher rates for humanities grads (15.4\%) and social science students (16\%). At the same time, underemployment became prevalent:almost $30 \%$ of the 1972 graduates ended up in nonprofessional and nonmanagerial jobs, and approximately one-half of the graduates took jobs unrelated to their majors, compared to some $10 \%$ in 1958 . Students' real starting salaries in industry declined from 1969 to 1975 by $23 \%$ for social science graduates, by $21 \%$ for mathematics graduates, and by $17 \%$ for doctoral engineer students. The ratio of university graduates' incomes to high school graduates' incomes dropped from 1.53 to 1.40 in 1973 . These changes in the prospects of graduates apparently had an impact, insofar as enrollment in American universities went down by a very dramatic $25 \%$ between 1969 and 1974 .

In Canada, the problem of student unemployment has crept up on us more slowly, or perhaps we have paid less attention to it. Any impact on universities was probably cushioned by the fact that undergraduate enrollment went up 10\% between 1969 and 1973, and not down as in the United States. In any case, we have until this very month been getting only dribs and drabs of information but not an overall picture with projections. For instance, one of the early studies by the Department of Manpower and Immigration was a survey in August of 1974 (18). It showed that only 14\% of Bachelors and Masters graduates "obtained professional employment." This looks like an unemployment rate of $86 \%$, but this is misleading. Manpower and Immigration did not count students who got jobs outside their fields of study. Thus we do not know the employment or unemploy. ment rates.

In the meantime, several universities have been taking a look at the situation. A University of Toronto survey in 1971 found that $13.3 \%$ of former students were unemployed nine months after graduation. Apparently one quarter of these "abandoned the search" for jobs and went on for further education. The University of British Columbia carried out a study in November of 1972 and found that the unemployment rate was $14.2 \%$ among those seeking jobs. It was considerably higher for students from Arts and Science, almost 19\%. Again, a large proportion of students in these fields had gone on to professional and graduate education programmes.

Newman (15) did surveys of University of Victoria students' employment experience in November of 1975 and 1976. (Table 1) The response rate was good for a single mail-out, $43 \%$ and $51 \%$ for each year respectively. The reported unemployment rates were $16 \%$ for 1975 graduates and $25 \%$ for those of 1976 . These rates are high, and the increase in 1976 indicates that the situation is getting worse. At the same time, a lot of students are going back for more education, $25 \%$ and $30 \%$ for the two years. Students' answers indicated that more than one-third of these would have preferred a suitable job if available.

The unemployment rates in these surveys presented a very serious picture. However there was reason to believe they were exaggerated. For one thing, it seems likely that the responders (approximately 50\%) would include an unduly high proportion of unemployed. This was illustrated when we looked at responses by University Departments: in one case just one of the four graduates responded. That person was unemployed, making the unemployment rate $100 \%$. Furthermore, one-third of the 1976 unemployed indicated they were unwilling to leave Victoria to find work, and another third wished to remain on Vancouver Island or at least within the province. 


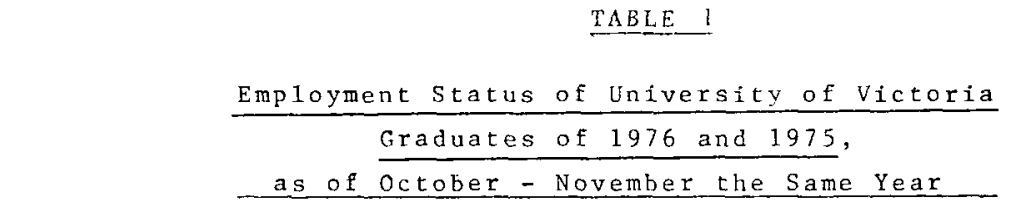

1. Number responding

$\frac{1976}{341}$

(51\%) $\quad \frac{1975}{311}$

$(43 \%)$

2. Employed ful1-time

$45 \%$

$52 \%$

3. Full-time students

$25 \%$

$30 \%$

4. Trave 11 ing

$2 \%$

5. Homemaking

6. Unemployed

7. "Seeking Work" (6 above plus people in 3,4 , and 5 who would prefer full-

time work if it were available)

TABLE 2

Average Participation and Unemployment Rates $(\%)$ in Canada for 1975 by Education Levels 1

Education levels

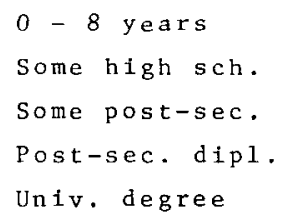

Unemp1. rates

8.2

8.0

6.4

$4 \cdot 3$

3. 0

6.9

Our contacts with students suggested still another phenomenon, that some students take time to find jobs and settle in. This view is supported by the average unemployment rates for Canada in 1975, as shown in Table 2. Not only do university graduates have the highest participation rate in the labour force, $82 \%$ as against $46 \%$ and $62.6 \%$ for elementary and high school graduates, but they also have the lowest unemployment rate, just $3 \%$ for the year compared to $8 \%$ for school level workers. It is notable that the unemployment rate for those with post-secondary diploma or certificate is higher, at $4.3 \%$.

However, unemployment rates by educational level fail to account for the youth factor. Labour Force surveys do not ordinarily pull out such data. However, they will on request. The data in Table 3 confirm the university surveys and everyones' hunches. Unemployment is concentrated in youthful members of the labour force, up to 
Participation and Unemployment Rates (\%) for Four Months in 1976 and 1977 in Canada and British Columbia for Youth $\left(15-24\right.$ years) and Adults (25+years) by Education Level ${ }^{1}$

\section{Canada}

\section{January 1977}

\section{$15-24$ years $\quad 25+$ years}

\section{Educ. leve 1}

Partic. Unemp1

59.1

February 1977

$15-24$ years $\quad 25+$ years

Partic. Unempl. Partic. Unempl.
$0-8$ years

$44.7 \quad 30.4$

Some high Sch.

$58.3 \quad 16.2$

$\begin{array}{ll}55.1 & 10.8\end{array}$

$79.3 \quad 9.0$

76.4

8.4

$58.9 \quad 15.2$

59.6

6.5

A11 levels

$43.4 \quad 10.0$

$62.5 \quad 6.5$

71.3

$4 \cdot 9$

69.4

4.7

81.3

$2 \cdot 8$

1 From Labour Force Survey 
Table 3 cont'd

Participation and Unemployment Rates (\%) for Four Months in 1976 and 1977 in Canada and British Columbia for Youth (15-24 years) and Adults (25+ years) by Education Level

British Columbia

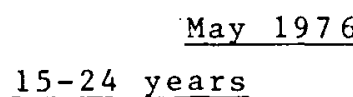

$25+$ years
August 1976

$15-24$ years

$25+$ years

Educ. level Partic. Unemp1. Partic. Unempl. Partic. Unempl. Partic. Unemp1.

$0-8$ years

Some high sch.

Some post-sec.

Post-sec. dipl.

Univ. degree

A11 leve1s
$38.6 \quad 29.9$

63.7

16.5

40.8

8.4

57.4

24.0

$40 \cdot 3$

6.4

79.6

16.4

60.7

6.4

70.1

6.0

70.4

$6 \cdot 5$

81.7

3. 8

60.4

6.4

65.4

16.8

73.9

13.3

61.0

5.8

83.5

5.6

67.5

5.7

85.4

6.8

71.1

6.8

84.8

7.0

80.9

5.6

1From Labour Force Survey Division, Statistics Canada

$\begin{array}{llll}75.2 & 12.0 & 60.3 & 6.0\end{array}$




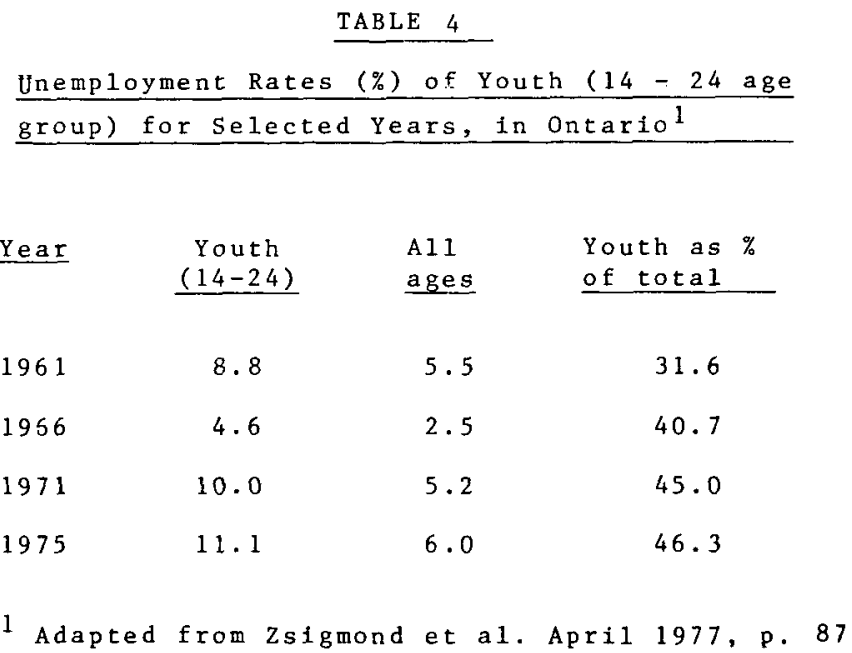

$16.8 \%$ of the total youth groups aged 15-24 years of age compared with 2.6 to $6.4 \%$ for the total older groups. However, within the youth group, university educated members consistently have the lowest unemployment rates, much lower than school level persons, and in 3 out of 4 months lower than individuals with a post-secondary certificate or diploma. And for the older group, the university graduates have less unemployment than the post-secondary diploma people at all four time periods.

The youth factor in unemployment is illustrated further in Table 4. Even when the overall unemployment rate in Ontario was just $2.5 \%$ in 1966, youth made up $40.7 \%$ of those unemployed. Today they constitute just about $50 \%$ of the unemployed in Canada.

At this point I would like to note that Table 4 and some of the remaining data in this paper are drawn from the 224 page report "Future Trends in Enrolment and Manpower Supply in Ontario" (23). The study was a joint product of Statistics Canada and the Ontario Educational Communications Authority, authored by Z. Zsigmond, G. Picot, M.S. Devereaux, and W. Clark. This was the first comprehensive study in Canada of employment and the labour force in education, and it is up to date. The fact that it is largely based on Ontario data is a limitation, but we can keep that in mind when thinking about the country or about particular provinces.

So youth constitute a disproportionate number of the unemployed. There are obvious reasons for this, like their inexperience and tendency to job hop, but the major cause at this time is probably the baby boom of the 1945-59 era. The number of youth (14-24 year olds) in the Canadian labour force increased from 1.3 million in 1953 to 2.8 million in 1975, and is projected to nearly 3 million in 1981, when the bulge starts to level off and decline. This, together with an unusual number of women entrants to the labour force, simply outpaced the production of new jobs, even though Canada led all other western industrialized nations in creating new jobs in this period (8).

At the same time, however, there has been an accelerating tendency for more people to take more education, as illustrated in the data for Ontario (Table 5). From 1966 to 1975 the proportion of people entering the labour market with some post-secondary edu- 


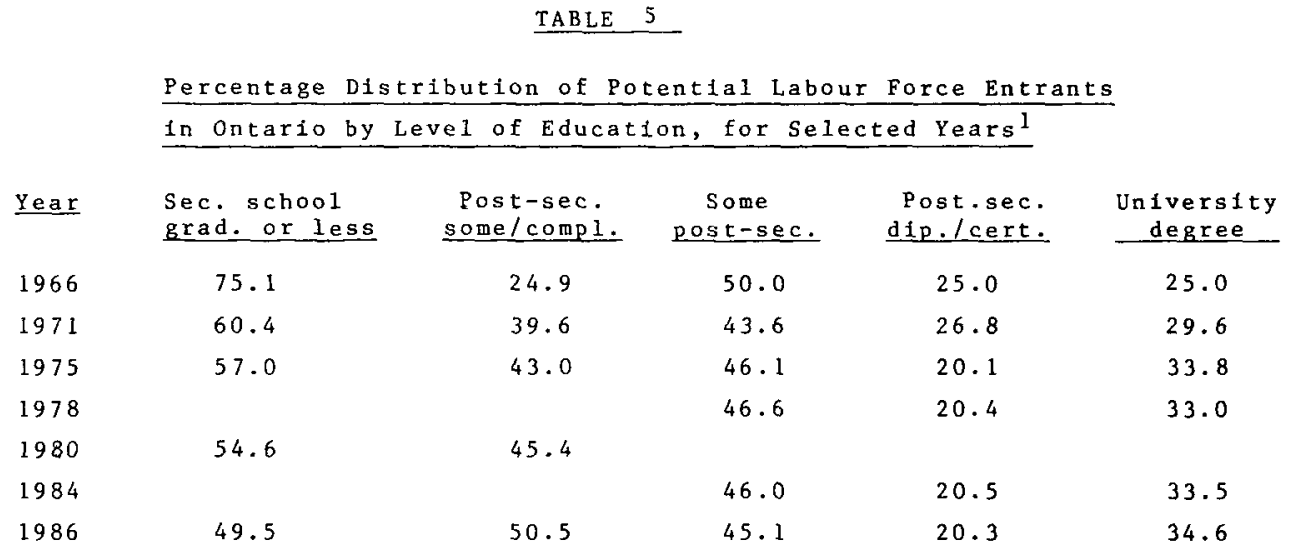

1 Adapted from zsigmond et al. April 1977, p. $79 \& 80$.

TABLL 6

$1972-75$ Spring Unemployment Rate by

Educationai Level and Age Group ${ }^{1}$

Educational level

Elementary

Some secondary

Completed secondary

Some post-secondary

Completed post-secondary

Total

${ }^{1}$ Data are for Ontario; adapted from Zsigmond, et al. April 1977, p.89.

cation has increased from $24.9 \%$ to $43 \%$ and is projected to $50.5 \%$ in 1986 . Within this trend there is a strong tendency for the increase in post-secondary entrants to be made up of relatively more university degree people while the proportion of those with a college diploma or certificate has declined and will level off.

Given this massive increase in the numbers of youth and a simultaneous tendency to get more education, especially at the post-secondary level, we could expect a relative increase in the unemployment rate for youth with a post-secondary education. However, this is not too evident (Table 6). At least for the period from 1972 to 1975 in Ontario, the unemployment rate for youth with a post-secondary education (5.3\%) is considerably lower than that for youth at other educational levels. This is illustrated in Figure 1. Unfortunately, university and college-technical graduates are not separated in the data. 


\section{Figure 1}

Graph of Average Spring Unemp loyment Rate $(\%)$ for 1972-75 in Ontario by Educationa1 Leve 1 and Age Group

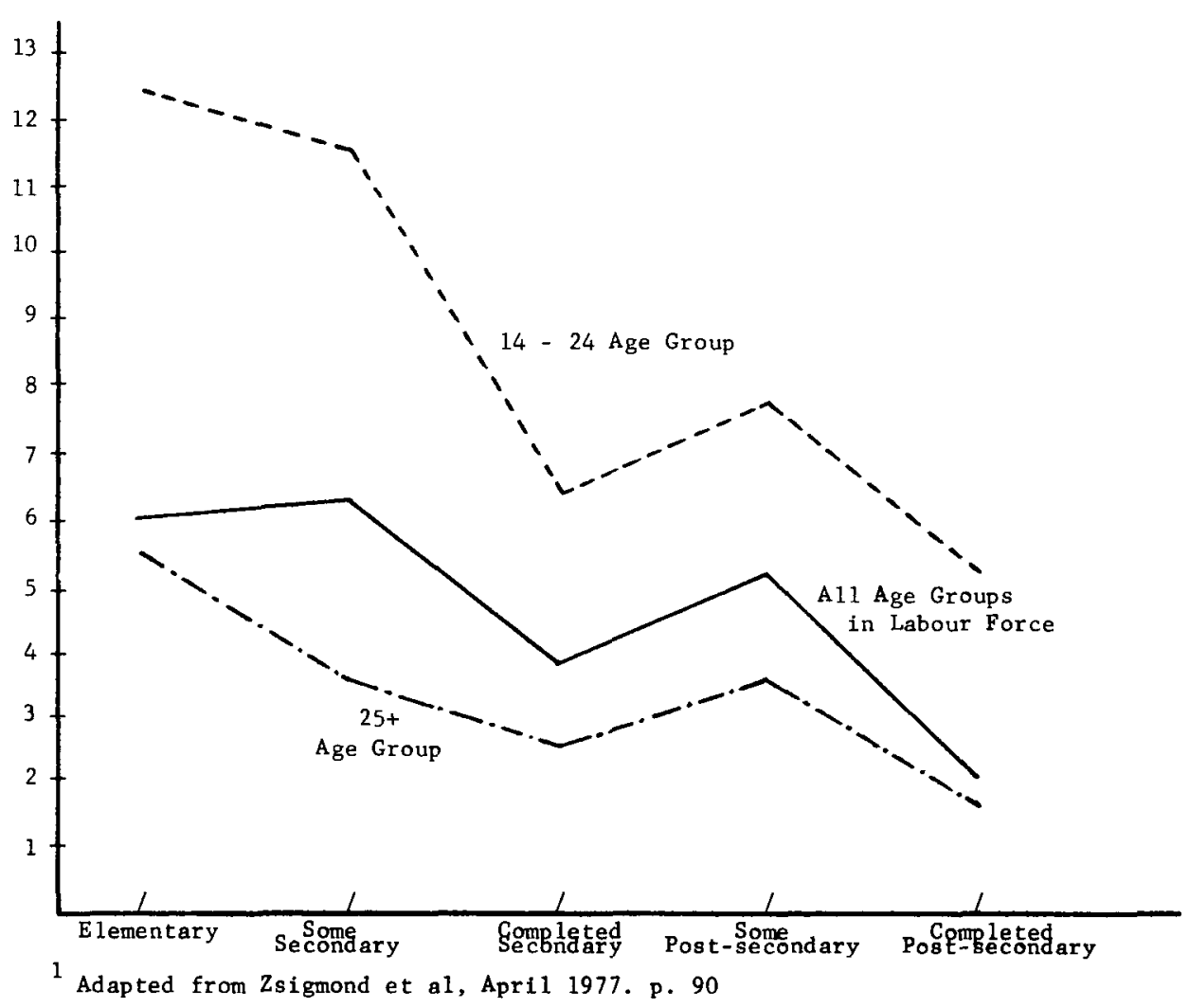

What about the problem of so-called underemployment? Table 7 indicates that in $197310 \%$ of degree holders in Canada and 14\% in Ontario were employed in jobs requiring less than two years post-secondary education. On the face of it, this study indicates that the problem of underemployment is insignificant. However, these are probably underestimates because they are based on all degree holders and not just recent graduates, and the two years post-secondary criterion is below the three or four year degree level. Apparently Zsigmond et al (23) could find no study which separated these variables.

Underemployment as defined by a salary below the Ontario government minimum for a particular educational level was calculated for 1974 college and university graduates (Table 8 ). According to this scale, $20 \%$ of college graduates were underemployed in the year of their graduation, and this was just about the same, $19 \%$, one year later. Note the large differences between fields of study: from $7 \%$ of students in the technical area to $61 \%$ in educational and household services. University graduates were doing somewhat better with $17 \%$ underemployed in 1974 , dropping to $11 \%$ in 1975 . Again, there are differences between disciplines, from 4 and $7 \%$ for engineering and business to 38 and $43 \%$ for general Arts and Science and secretarial and household science. 
TABLE 7

Percentage of Employed Degree-holders in Non-highly Qualified Jobs in $1973^{1}$

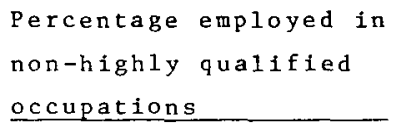

Ontarto

Canada

Breakdown by degree level for Canada:

Tota 1

General degree

Specialized undergraduate degree

Graduate diploma or certificate

Medical

Master"s

Earned doctorate

1 Adapted Zs1gmond et al. Apr11 1977, p. 94.

\section{4}

10

10

21

10

8

0

6

0

Table 8

Proportion of College and University Graduates Employed Full

Time and Earning Less than the Ontario Minimum for their Respective Post - Secondary Categories, by Field of Srudy ${ }^{1}$

Field of Study

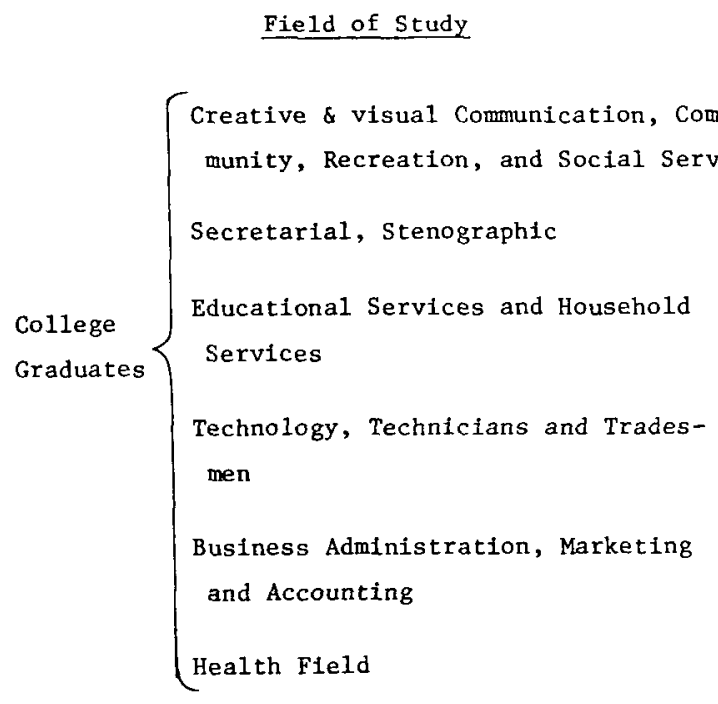

Total
Per cent earning less than $\$ 7,000$ in Sept. 1974
Per cent earning

less than $\$ 8,000$

In Sept. 1975 
Table 8 cont'd

Proportion of College and University Graduates Employed Full

Time and Earning Less than the Ontario Minimum for Their Respective

Post - Secondary Categories, by Field of Study 1

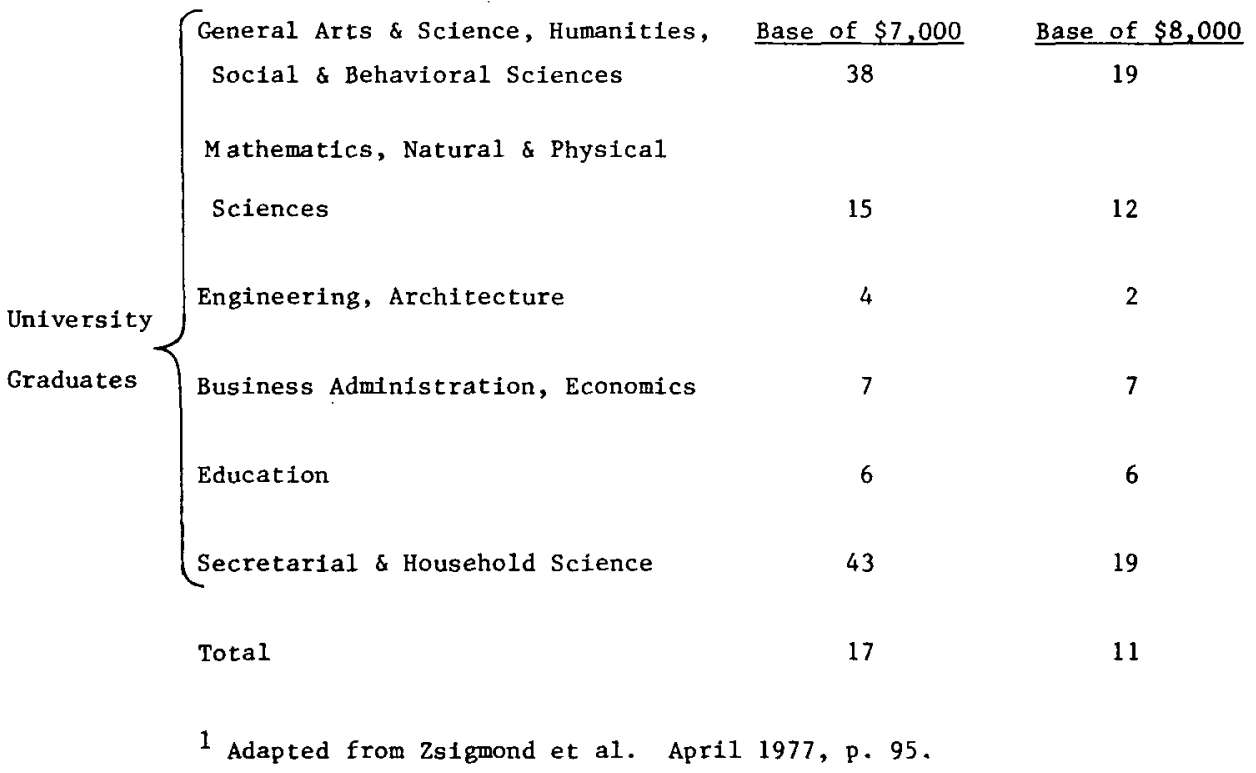

This differential by field of study in so-called underemployment is manifested in differential unemployment rates for the same groups (Table 9). In this case, the overall unemployment rates for college graduates ( 9 and $6 \%$ ) are less than for university graduates (11.9 and 7.2\%). Those in the technical area fare best among college graduates, while those in engineering, business, economics, health and education do best among university graduates. Those with the highest unemployment rates were in college creative and visual communications and community service programmes, and in general Arts and Science and Fine Arts in university. Note also that they start to do better in their second year, in terms of both unemployment and underemployment.

It is quite clear that the general programmes at both university and college are the source of students who have some difficulty finding suitable employment. On the other hand, it is the same general programmes, at least in university, which are the source of the many students who then take professional training in areas such as medicine, teaching, and law, or take graduate studies. This is illustrated in the data (Table 10) for the University of British Columbia (17). A large proportion, $12.6 \%$ of students go on for professional degrees, and another $12.4 \%$ go for advanced studies $(6.7 \%$ in graduate programmes and $5.7 \%$ doing qualifying studies). One very important result is that the overall unemployment rate remained $12 \%$ ! It is apparent that students are making adjustments to the situation. On the other hand, some will probably have to face the problem again later. Can- 
Adjusted Unemployment Rates (\%) for Spring 1974 Ontario College and University Graduates 1 by Eield of Study When surveyed in september of 1974 and 1975

\begin{tabular}{|c|c|c|c|c|c|c|c|}
\hline College gradu & tes & & & niver & sity 8 & grade & tes \\
\hline & & & & achel & $\tilde{r}^{\prime} s$ & Post & -grad. \\
\hline rle 1a of scuay & 1974 & 1975 & slese ol sluay & 1974 & 1975 & 1974 & 1975 \\
\hline Creative and Visual Communications & 19.5 & 9.6 & Arts and Science & 20.2 & 7.5 & $\cdots$ & $\ldots 3^{3}$ \\
\hline $\begin{array}{l}\text { Community, Social and Recreational } \\
\text { Services }\end{array}$ & 19.0 & 6.7 & Fine Arts, Languages, Literature & 21.6 & 9.9 & $\cdots$ & $\cdots$ \\
\hline $\begin{array}{l}\text { Technology - Applied Natural and } \\
\text { Physical Sciences }\end{array}$ & 3.1 & 3.1 & Social and Behavioral Sciences & 19.4 & 11.6 & 3.7 & 8.4 \\
\hline $\begin{array}{l}\text { Practical Arts - Technicians, } \\
\text { Tradesmen, Craftsmen }\end{array}$ & 4.4 & 4.4 & $\begin{array}{l}\text { Mathematical, Natural and Phys- } \\
\text { ical Sciences }\end{array}$ & 12.8 & 7.6 & 9.3 & 12.7 \\
\hline $\begin{array}{l}\text { Secretarial, Stenographic and } \\
\text { Clerical Arts }\end{array}$ & 7.9 & 6.9 & $\begin{array}{l}\text { Engineering, Architecture and } \\
\text { Applied Sciences }\end{array}$ & 7.4 & 4.3 & 11.1 & 11.4 \\
\hline $\begin{array}{l}\text { Business Administration, Finance, } \\
\text { Marketing and Accounting }\end{array}$ & 7.1 & 6.1 & $\begin{array}{l}\text { Business Administration and } \\
\text { Management Sciences }\end{array}$ & 4.3 & 2.3 & 7.9 & 2.4 \\
\hline Health & 7.9 & 4.8 & Economics & 8.1 & 7.7 & $\ldots$ & $\cdots$ \\
\hline Education and Related Services & 9.8 & 13.3 & Medical and Health Services & 6.1 & 3.9 & 0.9 & 0.8 \\
\hline Household Sciences & $\cdots$ & $\cdots$ & Education & 7.2 & 3.3 & $\cdots$ & $\cdots$ \\
\hline & & & Household Sciences & 10.7 & 7.6 & $\cdots$ & $\cdots$ \\
\hline Tota1 & 9.0 & 6.0 & Total & 11.9 & 7.2 & 4.0 & 4.2 \\
\hline
\end{tabular}

1 The unemployed includes graduates without full-time jobs who were seeking work; post-graduate includes degrees, masters and doctorates.

2 Adapted from zsigmond et al. April 1977, p. 93.

3 ... Excluded because sample size was zero or very small. 
TABLE 10

Percentage of University of British Columbla's 1975 Graduates by Field of $S t u d y$ who were Unemployed or Taking Further Education when Surveyed in November - December 1975

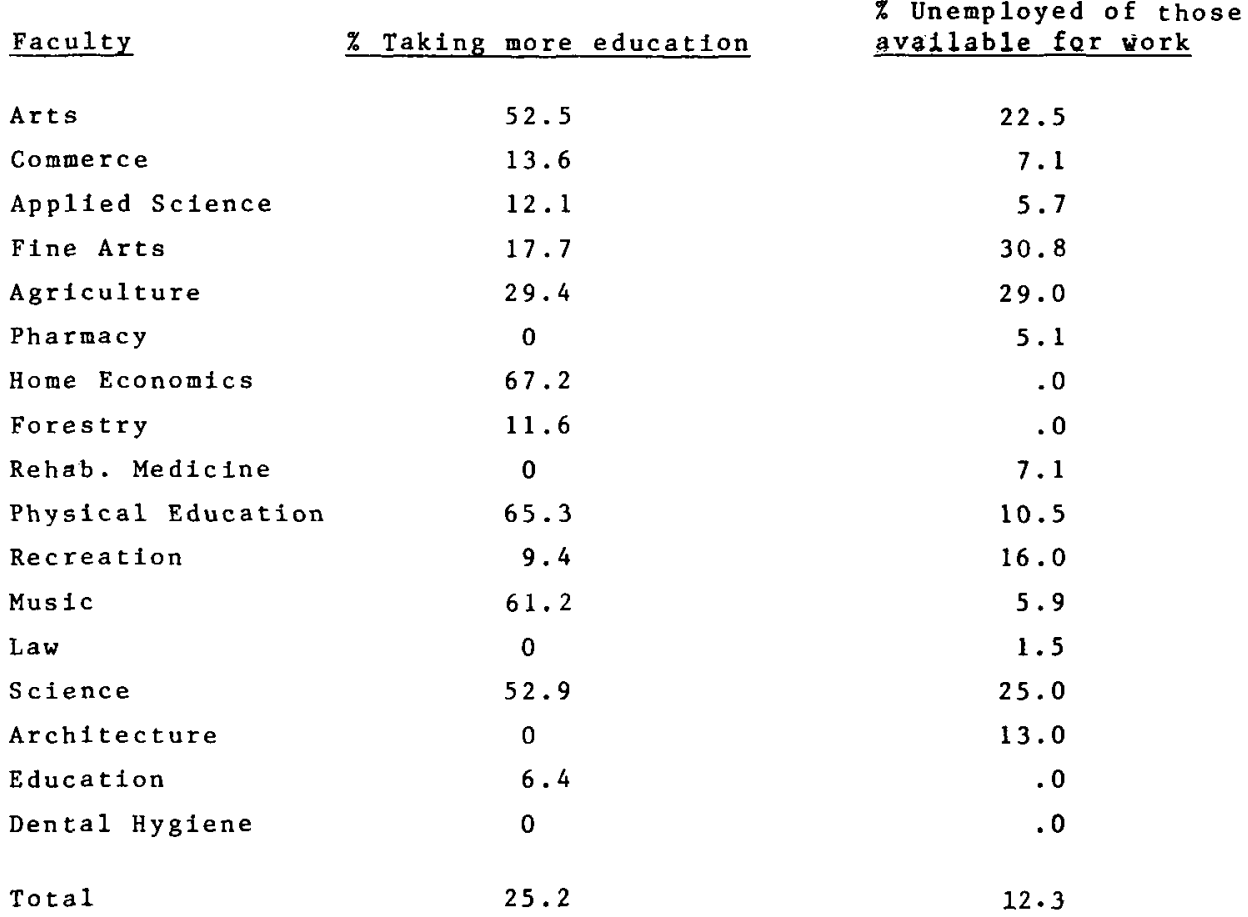

adian universities are turning out about 2,000 Ph.D.'s and 10,000 Master's a year, and these are starting to have difficulty finding suitable jobs.

What does all this mean, for students, and for colleges and universities? Looking at students first, it is clear that there is some unemployment among students, and for those affected, it is serious; unemployment can cause disillusionment and hardship. However, the impact of college and university is generally to reduce unemployment among youth, and at the same time, to increase substantially the participation rate of the recipients in the labour market. These are the main facts for our society and its economy, and for universities and students. They constitute the essential background for any discussion of the problem.

Then, within this context, we may note that many students have to work at getting a job now - which may not be a bad thing; that they may take months or even a year or more to explore jobs and settle in a career - and this is normal for youth and could only be prevented by an airtight system for slotting people into jobs and holding them there. Quite a few of the highly educated youth are taking jobs, at least initially, which require less education - but this is not necessarily bad, and we should not expect all university 
Employment Experience of University of V1ctoria, 1976 Graduates

in Terms of Job Level, relevance to Training, and Job Satisfaction

$\%$ of Students

Students in university jobs

Students in non-university jobs

Students in jobs related to education

Students in jobs not related to education

In non-university jobs, not related to education

Total sample
$65 \%$

$35 \%$

$50 \%$

$50 \%$

$33 \%$

$100 \%$
$\%$ Satisfied

$92 \%$

$47 \%$

$91 \%$

$61 \%$

$44 \%$

$76 \%$ 
graduates to be suited for so-called university level jobs. We should also note that unemployment and so-called underemployment are concentrated in graduates of certain fields of study, and potential students and educational institutions should be alert to this. Finally, more and more college and university graduates are going on for further education, in professional programmes and in graduate studies, usually with the idea of developing a more desirable career and job, but now these are also running into employment problems.

Nevertheless, I would say that in general, college and university are serving students quite well. It could be better, especially in some fields of study, but students are doing comparatively well in the world of work. And I would say that in general, students are adjusting to the changing circumstances of education and the labour market, and most are satisfied. Newman (15) looked at student adjustment in the survey at the University of Victoria (Table 11). Just over $75 \%$ of the graduates were satisfied with their jobs. For the $35 \%$ in non-university level jobs as defined by the CCDO, $47 \%$ were satisfied. Of the $50 \%$ who were in jobs unrelated to their training, $61 \%$ were satisfied. Even for those in jobs which were non-university and not related to their education, $44 \%$ were satisfied with their jobs. These satisfaction rates are surprisingly high.

If unemployment is not as rampant among students as some public statements and the media would have us believe, it is a major problem for youth, and especially for the uneducated youth. According to Collins' (7) analysis of the 1971 Canadian census data, there were 147,000 youth 14-24 years of age who were out of work, and another 543,000 who were not in school or other education, for a whopping total of 689,000 youth who were idle. This respresents about $30 \%$ of this age group. This is the group about which society should be concerned; this is the group which is somehow neglected by society as well as by schools, colleges, and universities.

Now turning to the colleges and universities a crucial question is whether the current trends in unemployment and underemployment of post-secondary students are shortterm or long-term. Is the investment value in college study really declining as Bird (3) and Freeman and Hollomon (12) assert? Is this country developing an oversupply of people with higher education, more than our labour market needs? Witmer (20) has questioned and to some extent refuted the views of Freeman and Hollomon that the investment value of a college education has declined. He also presents impressive evidence that this kind of crisis in higher education, with its forecasters of doom, has occurred periodically in history since 1890 .

About the oversupply hypothesis, Freeman has argued that it is happening in the United States, with important social implications for the country, in terms of the class structure and social unrest. Our Minister of Manpower and Immigration, Mr Cullen (8), said that Canada started to produce more post-secondary graduates than there were jobs requiring such education a few years ago. Apparently there are data on this crossover of supply and demand for people with higher education. One study shows that the crossover started in 1971 when there were more jobs for people with grade twelve education or less, than there were workers with grade twelve or less. This excess of such jobs is projected to be about 1 million by 1985 . Conversely, the supply of workers with some or completed post-secondary education has apparently passed the number of jobs requiring such education, and is projected to be an excess of about $1,900,00$ by 1985 .

This looks like a serious problem of over-education in Canada. However, this kind of 
study needs to be validated with all available data and on different assumptions. For one thing, such a projection assumes that the educational requirements of occupations will remain relatively static. This assumption is questioned on several counts. It is also possible that, as the need for work hours levels off and even declines, we may well have to educate people for idleness, or provide educational opportunities as an outlet for their spare time. In other words, we may have to forgo the economic model of man and develop a more socially and culturally oriented model, what we may call the citizenship model.

In the meantime, how should universities and colleges respond to the data and trends of education and employment? One response would be to over-react. Some colleges and universities in the United States are asking business and industry what they want in a graduate and are developing programmes to produce directly saleable skills. However, such a move could result in recurrent cycles of boom and bust for students and universities alike. There is an unavoidable time lag between demand for particular occupational skills and the production of students with those skills, and in the meantime the demand could collapse. Moreover students with such an education could land up in a dead end, and find it difficult to move sideways or back onto the educational career ladder. In any case, such an adjustment by universities would not create jobs.

Another response would be to sit tight and wait for the situation to change. The problem with this is that a lot of young people would unknowingly invest in programmes which can hardly give them the future they expect. For example, Goddard (13) predicted back in 1970 that universities would be over-producing Ph.D. psychologists in Canada, but psychology departments sat tight and now graduates must go into work areas of psychology for which they were not trained. In the United States, more and more students have been going into psychology until today there are more students taking graduate studies to become psychologists than there are psychologists in the American Psychological Association (22). This trend is only now being faced, probably five to ten years later than would have been desirable. The sit-tight response also runs the risk of letting economics produce unplanned changes, or of leaving it to governments to determine university policy.

A third response would be to limit or cut back enrollment and so reduce the number of students entering the labour market. Such a response is deceptively simple. What it would do is put more of the less educated on the labour market. Any arbitrary limitation of enrollment could meet resistance from many people who want that choice for their children, and so erode public support of the universities.

A fourth response would be to analyze the situation in detail and develop adjustments that are consonant with the proper functions of the university on the one hand and with the realities in society and the world of work on the other.

Making adjustments would call for some kind of planning. Yet this is a risky business; which requires good and complete data. The.Principal of McGill University in a speech to the Montreal Rotary Club (2) said that Manpower data are too shaky for any but the broadest kind of planning. He cited the instance of the then Minister of Manpower and Immigration, Mr. Andras, writing in the fall of 1976 to the provincial ministers responsible for universities, that of the 2,500 Canadians and landed immigrants who received Ph.D.'s in the year $1974-75$, only 125 to 150 had obtained university positions. Principal Bell reported that in the meantime the Association of Deans of Graduate Schools had 


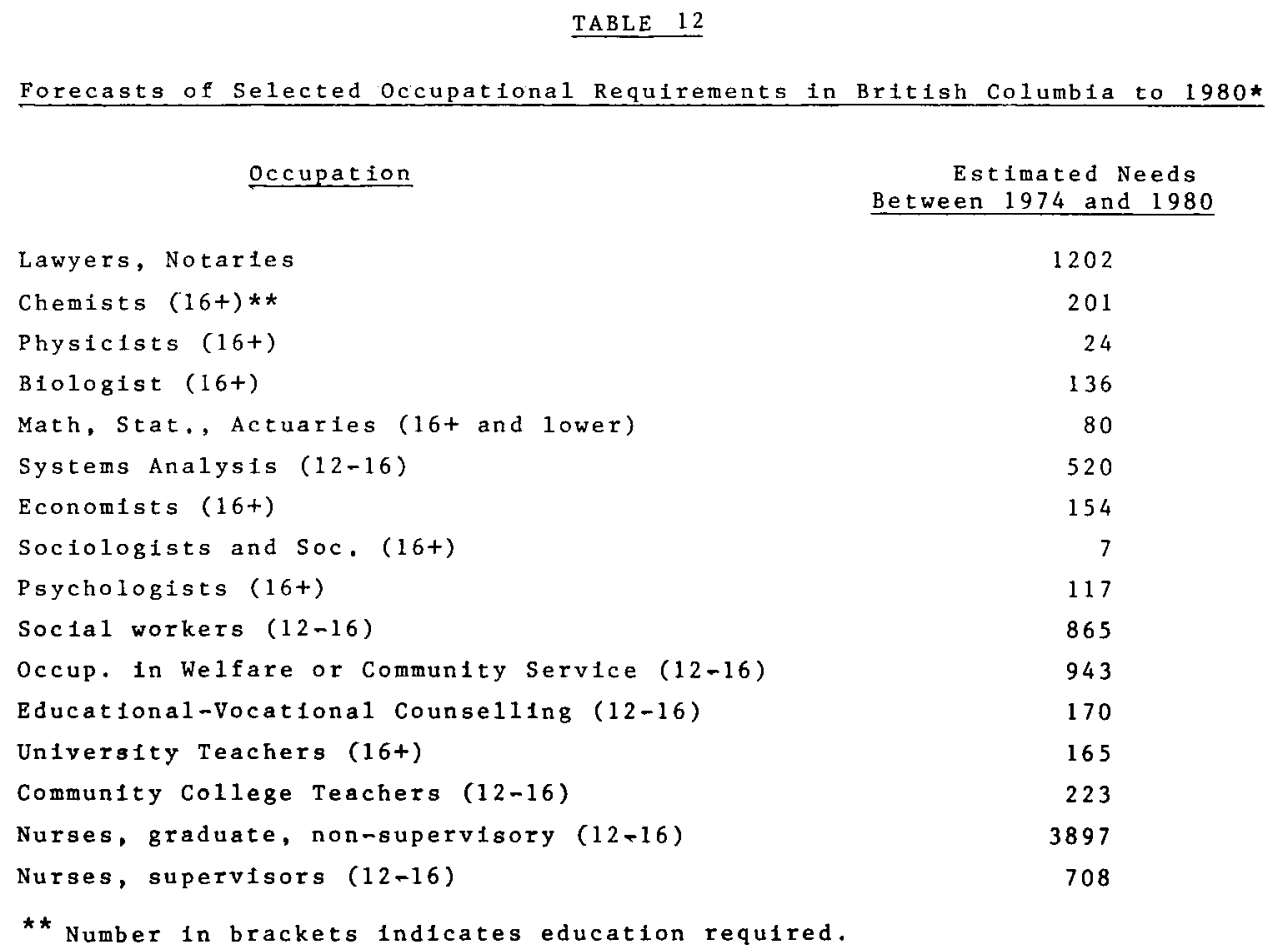

Occupation

Lawyers, Notaries

Chemists $(16+) * *$

Physicists $(16+)$

Biologist $(16+)$

Math, Stat., Actuaries (16+ and lower)

Systems Analysis $(12-16)$

Economists $(16+)$

Sociologists and Soc. (16+)

Psychologists $(16+)$

Soc1a1 workers $(12-16)$

occup. In Welfare or Commuity Service (12-16)

Educational-Vocational Counseling (12-16)

University Teachers $(16+)$

Communty College Teachers (12-16)

Nurses, graduate, non-supervisory $(12-16)$

Nurses, supervisors $(12-16)$

** Number in brackets indicates education required.

collected data showing that only 102 of the 1,739 Ph.D.'s granted that year did not have jobs. One of the sad aspects of this example is that Mr. Andras and Principal Bell were equally guilty of giving partial information that biased the case in their respective directions.

To illustrate the difficulties with planning more concretely, consider another example. The Department of Manpower and Immigration has recently developed the Canadian Occupational Forecasting Programme (COFOR) as a means of giving relatively long-range estimates of manpower needs in Canada. The Economic Analysis and Forecasts Branch of the Department, in the Pacific region, derived forecasts for the Province of British Columbia and published them in January 1975 (10). Some of the estimated needs between 1974 and 1980 are presented in Table 12. Demand looks rather strong in some occupations, such as law, social work, welfare work, educational-vocational counselling, university and college teaching, and nursing.

It was just fourteen months later that the Pacific Region office of the Department of Manpower came out with its Forward Occupational Imbalance listing (FOIL) and presented a dramatically different picture (5). The two-year predictions in Table 13 were now for an excess supply of social workers and welfare workers, of school and university teachers, of nurses, and of several management occupations into which university graduates have traditionally gone. The changes can be explained, of course: the COFOR predictions were based on data up to 1972 when Canada and especially British Columbia were still in an expansionary trend, the data become less reliable when reduced from the 
Forward occupational Imbalance Listing (FOIL) Eor Selected Occupations as of March, 1976

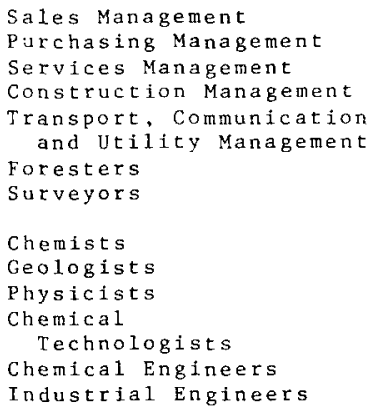

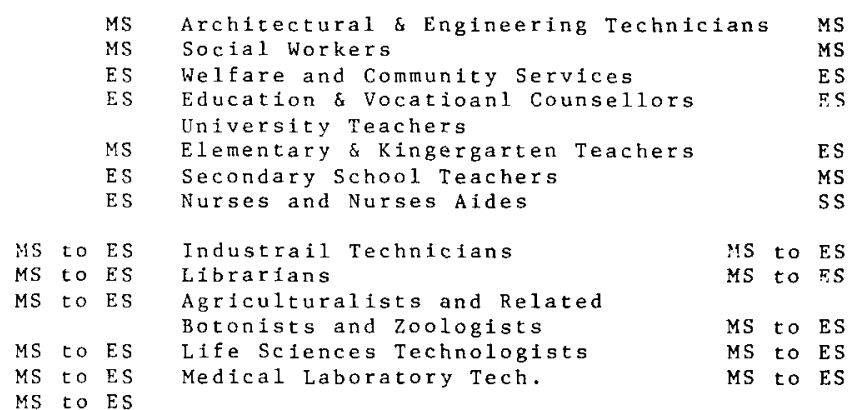

CODE :

ES - Extreme excess supply

MS - Moderate excess supply

SS - Slight excess supply

national to a provincial level, some of the occupations like social services and nursing are "volatile" and an unforseen change in government was in the offing. Nevertheless, this kind of variability in the employment picture does not facilitate planning with any confidence, whether by educational institutions or students.

It would be short sighted if our education ministers, or the Minister of Manpower and Immigration, or universities and colleges were to take isolated bits of data like this and use them as a basis for policy. For example, the proposal to place greater emphasis on vocational education is not consistently and strongly supported by data. Authors Daniel and Whittinghan (9) properly hedge their supporting conclusions with "Given the lack of homogeneity, however, the data still suggest that, an average ..." (emphasis added) Another study, by Poddar (16) found that Canada Manpower Counsellors rated unemployed clients with university degrees as much more difficult to place in jobs. He pointed out that this is "understandable" because CMC clients are predominantly blue collar, but he failed to note the corollary of this, that the $\mathrm{CMC}$ is often the last resort of university educated persons and that employers typically do not look to Manpower for such people. In the present paper, some of the data favours the university degree (Tables 2,3, and 6), some favours the vocationally trained person (Tables 7,9, and 10), and some studies favour both positions (Table 8 ). The data in this area are too limited and variable to warrant simple solutions or major policy decisions.

On the other hand, it would be equally foolhardy for universities and colleges to ignore the changing realities in our society. We should examine our assumptions and our practices.

A widely held assumption in universities is that academic achievement is a measure of future success. However, the facts are that there are few reliable relationships between students' achievement in university and their subsequent achievement in various jobs and occupations. The American College Testing Program reviewed the evidence on this proposition and confirmed it in yet another study (1). Academic ability as measured by school and college grades or test scores predicts further academic achievement, but not 
success in nonacademic areas such as leadership, speech, writing, communication, planning, and decision making. These latter may be predicted by noting students' involvement and competence in these activities. On the other hand, success in these activities is generally unrelated to academic achievement. The authors conclude that there are other talents beside the academic, and that these may be of more consequence in the real world.

These findings are congruent with the fact that employers also identify other talents and often emphasize them when hiring students. In numerous surveys, personal qualities are nearly always ranked first, qualities such as maturity, initiative, enthusiasm, motivation, poise, and the ability to work with others. The three top requisites in a Victoria survey were communication and interpersonal skills, willingness to work, and willingness to be supervised and trained. And most employers look for some practical work experience.

Findings like these are receiving much more attention today. However, it would be a grave mistake to simply grant the proposition that academics are not important. In fact, they are necessary. The studies which show that academic talent is not related to success in an occupation usually grant the case by virtue of studying individuals who gained entrance to their occupations by meeting certain criteria of academic achievement. Students qualify for and gain entrance to occupations requiring particular degrees by learning the language of and being able to communicate in that discipline, and by being able to observe, analyse, and report on some aspects of the reality in that area, for instance in the area of disease and medicine. This kind of achievement is not only necessary to gain entrance to many "higher level" occupations, but serves the entrants rather well in surviving in those occupations.

Nevertheless, the fact that the academic criteria of achievement do not predict differentially within occupations should give academic institutions pause, and should be researched. What is missing in academic programs? Allow me to speculate for a moment. In my view there are three broad abilities or competencies which are important in a wide variety of circumstances: first, the ability to observe and discriminate, second the ability to think and analyse, and third, the ability to communicate. Many university programmes today offer little or no training in observation, and when they do, it is restricted to narrow bits of reality. The Humanities teach students to observe the spoken word (lectures) and the written word (selected library books), to think about these, and to communicate about them. The Social Sciences do a little better in that they may have students also observe, think and communicate about the "reality" of laboratory experiments on animals and people and about social surveys. The Physical Sciences usually add another "reality", that of their laboratory experiments.

However, in this technological age there is no need to restrict reality to the spoken and printed word, nor even to library books and laboratory equipment. The media and industry could provide other aspects of reality for observation, analysis, and reporting. And audio-visual equipment makes it possible to use the case study method in nearly all disciplines today. This approach is vulnerable to casual standards, but if it were adequately planned and conducted in a disciplined laboratory manner, it would upgrade education.

I suspect that such an emphasis on observation, analysis, and reporting, on a broader sample of realities, would make academic achievement predictive of success on many jobs. This is, of course, to assume appropriate standards of academic achievement which have been slipping in many of our educational institutions.

I would prefer this model to that of providing more work-related electives. While the 
judicious use of electives with some solid content would contribute to more balanced learning, it would be difficult to reverse the recent tendency to multiply electives in school and university with little attention to content and challenge. On the other hand, universities should be more active, and collaborate with government, business and industry, and labour, in planning co-op programmes and other kinds of study-related experience. Such programmes not only serve students well, but they put university instructors in touch with the realities of the outside world, and this in turn can facilitate more balanced learning in the classroom.

Yes, there is an urgent need to upgrade and develop the academic model of education. And universities should take a critical and realistic look at their generalist programmes in Arts and in Science, and at the very least they should provide information and counselling for students about their prospects. Nevertheless, there are other talents, the personal-social, and universities cannot afford to ignore them or to treat them with derision. Administrators and especially instructors should be alert to the personal-social development of students. And student services, notably counselling, manpower, and health, together with departments like psychology, should take a more active consultation and teaching role to promote personal-social development.

I cannot end this paper without mention of the university's role in producing, not just workers, but citizens. The Carnegie Council on Higher Education (6) found that college graduates are better citizens; they participate more in voluntary activities, are more likely to be active citizens and vote, are better consumers and preservers of our resources, are healthier, and lead more productive lives.

In this era and for the future, the demands on citizenship will be heavy. There must be, as Leon Botstein has said (4), greater scientific literacy if citizens are to participate in complicated decisions about things like resources and pollution, about energy and biological engineering. People must achieve a connecting historical perspective if they are to exhibit a judgment that goes beyond the stimulus-response here-and-now. And people must learn to handle idleness, and play, in a world of decreasing work hours. One of the special challenges for our educational institutions will be to produce citizens who are both achievement oriented and confortable with idleness. As mentioned previously, continuing education may well be one of the outlets for people who have time on their hands.

Another way in which universities and colleges should contribute to citizenship is by rationalizing and emphasizing the uniqueness, dignity, and freedom of the individual in society - not only in society but in the group, in the classroom, in the city, and in and under the bureaucracy. R. J. Williams has emphasized the centrality of individualism and freedom in his book You Are Extraordinary (19). He cites the case of a student who lacked talent in organic chemistry but with other talents and especially skillful hands became a highly successful surgeon. He describes how Robert Schumann's idiosyncratic right hand prevented him from becoming a piano virtuoso, so he turned to composition, leaving a record that otherwise would not be part of our civilization. The university has usually nurtured and maintained the uniquely curious and talented in a scientific and literary way. It must continue to do this. But it is also important to research and foster and teach individualism and freedom in terms of other idiosyncracies and talents and life styles, especially in an era which could smother the person. In these pursuits of better citizenship, colleges and universities must take the lead. 
In conclusion, the long-term impact of college and university on students is very positive in terms of high participation rates in the labour force and of low unemployment rates. The short-term picture is less positive. College and university students are experiencing considerable unemployment. However, this is largely a youth phenomenon, and compared to other educational levels college and university students are experiencing the least unemployment. Moreover, students, like most new entrants to the labour force, often take one or two years to settle in to steady jobs. A rather high proportion of students in some fields like Arts and Science are experiencing unemployment. While universities do not create unemployment, they would do well to examine their assumptions and practises in the light of reality. Academic talent is but one of several talents, and the others, such as willingness to work, ability to work with others, and leadership are often more important in the real world. Many academic programmes neglect the basic competencies of observation, thinking, and communication, and or apply them to narrow bits of reality. Universities should educate for citizenship, emphasizing personal development, scientific literacy, historical perspective, and the uniqueness, dignity, and freedom of the individual in society.

The author wishes to acknowledge the invaluable assistance of Jessie Wong, who was supported by a grant from the Provincial Employment Fund.

\section{References}

1. ACT Research Report. Varieties of accomplishment after College: Perspectives on the meaning of academic talent. Iowa City, Iowa: American College Testing Program. 1974

2. Bell, R. E., Cited in McGill Reporter, February 23, 1977.

3. Bird, C., "Where College fails us," Signature, June 1975, 43.

4. Botstein, L., "College could be worth it," Change, December 1976.

5. Career News for Students. Economic Analysis and Forecasts Branch, Department of Manpower and Immigration, Pacific Region, March 1976.

6. Carnegie Council on Policy Studies in Higher Education. Cited in Newsweek, 26 April, 1976

7. Collins, K., Youth and employment: A source book. Ottawa: Canadian Council on Social Development, December 1976.

8. Cullen, B., Notes for an address, to the Canadian Council on Social Development, January 1977.

9. Daniel, J., and Wittingham, F. Labour market experience of out-of-school youth. Manpower Research and Development Division, Department of Manpower and Immigration, Ottawa.

10. Forecasts of occupational requirements in British Columbia to 1980. Based on the Canadian Occupational Forecasting Program: COFOR. Economic Analysis and Forecasts Branch, Department of Manpower and Immigration, Pacific Region, January 1975.

11. Freeman, R. B., "Overinvestment in college training." Journal of Human Resources, 1975, 10, 287-311.

12. Freeman, R., and Holloman, J. H., "The declining value of College going," Change, December 1976.

13. Goddard, G. V., "Ph.D. training: The end of an era," The Canadian Psychologist, 1970, 11(2), 133-135.

14. Howe, H., II., The value of College: A non-economist's view. Cited in an address to the Atlanta Historical Society, November 1975. New York, Office of Reports, Ford Foundation.

15. Newman, J., Employment Survey of University of Victoria Graduation, 1976. Counselling Centre, University of Victoria, Victoria, B.C. 
16. Poddar, A. K., An analysis of CMC Counsellors' views and decisions respecting unemployed clients. Strategic Planning and Research Division, Department of Manpower and Immigration, Ottawa. 17. Post graduation activities of 1975 UBC graduates in selected Faculties. Office of Student Services, University of British Columbia, February 1976.

18. Supply and demand salaries - New graduates of universities and community colleges. Economic Analysis and Forecasts Branch, Department of Manpower and Immigration, 1975.

19. Williams, R. I., You are extraordinary. New York: Pyramid Books, 1967.

20. Witmer, D. R., Rates of return on investments in education 1890-1964. Address to Wisconsin Educational Research Association, Cardinal Stritch College, Milwaukee, 1971. Revised 1976.

21. Witmer, D. R., "Is the value of College really declining?" Change, December, 1976

22. Woods, P. J., "Careers: New models, new roles, new work," The Monitor, American Psychological Association, January 1976.

23. Zsigmond, Z., Picot, G., Devereaux, M. S., and Clark, W., Future rends in enrollment and manpower supply in Ontario. Ottawa: Statistics Canada, April 1977. 